\title{
PENGEMBANGAN BAHAN AJAR BERBASIS SCREAMBLE PADA MATA PELAJARAN AKIDAH AKHLAK POKOK BAHASAN AKHLAK TERPUJI NABI DAN RASULKELAS IV MI NU PURWOSARI METRO
}

\author{
Iim Lumiani, Muhammad Yusuf, Binti Khoiriyah dan Masrurotul Mahmudah \\ Institut Agama Islam Ma'arif NU Metro Lampung \\ $\underline{\text { lumiani141014@gmail.com }}$
}

\begin{abstract}
ABSTRAK
Pendidikan merupakan suatu proses dalam rangka mempengaruhi peserta didik supaya mampu menyesuaikan diri sebaik mungkin dengan lingkungannya. Untuk itu dalam proses pembelajaran diperlukan suatu metode pembelajaran yang dapat membuat peserta didik itu memiliki rasa nyaman, aman dan senang dengan mata pelajaran yang digunakan. Maka metode pembelajaran yang digunakan dalam penelitian ini adalah metode pembelajaran screamble. Screamble merupakan salah satu metode pembelajaran yang dapat meningkatkan konsentrasi dan kecepatan berpikir siswa. Jenis penelitian ini adalah penelitian dan pengembangan $(R \& D)$. Peniliaian bahan ajar ini menggunakan angket, yang dinilai oleh ahli materi, ahli media. Pertanyaan untuk setiap angket memiliki jumlah butir soal yang berbeda sesuai dengan ahli masing-masing. Dalam uji coba itu ada dua tahapan yaitu uji coba terbatas dengan 6 orang siswa dan uji coba pemakaian dengan 27 siswa. Dalam penelitian ini dilakukan revisi bahan ajar untuk masingmasing ahli sebanyak dua kali, yang bertujuan untuk meningkatkan kualitas dari bahan ajar yang dikembangkan.Dari penelitian yang dilakukan diperoleh hasil validasi dari masing-masing ahli seperti ahli materi memperoleh skor sebesar 3,5, dan ahli media memperoleh skor sebesar 3,4, serta dalam uji coba terbatas dan uji coba pemakaian yang dilakukan oleh guru yang memperoleh skor 3,6 dan siswa mendapatkan skor sebesar 3.76 dengan kategori sangat baik. Sehingga bahan ajar berbasis screamble yang dikembangkan sangat layak digunakan dalam proses pembelajaran.
\end{abstract}

\section{Pendahuluan}

Bahan ajar merupakan suatu komponen yang penting dalam pembelajaran. Dalam mengembangkan bahan ajar harus disesuaikan dengan kurikulum. ${ }^{1}$ Bahan ajar yang akan pendidik sampaikan harus mengacu pada tujuan kurikulum. Bahan ajar

\footnotetext{
${ }^{1}$ Departemen Pendidikan Nasional Direktorat Jenderal Manajemen Pendidikan Dasar dan Menengah Direktorat Pembinaan Sekolah Menengah Atas, Panduan Pengembangan Bahan Ajar, Tahun 2008, hlm.8
} 
yang biasa pendidik gunakan masih bersifat konvensional, sehingga belum ada variasi dalam proses pembelajaran. Selain itu, bahan ajar idealnya harus disesuaikan dengan kondisi yang ada diligkungan setempat agar pembelajaran lebih bermakna. Sehingga guru mempunyai kebebasan dalam mengembangkan suatu bahan ajar yang disampaikan tanpa menyimpang dari tujuan pendidikan.

Sebagai suatu sistem, maka pengembangan bahan ajar adalah gabungan dari berbagai komponen pembelajaran. Bahan ajar merupakan suatu bahan yang dibuat dari sumber belajar yang disusun secara sistematis. Sehingga pengembangan bahan ajar itu berhubungan dengan proses pembelajaran dengan tujuan akhir pembelajaran tepat sasaran.

Tujuan pengembangan bahan ajar adalah untuk menghemat waktu bagi guru (pendidik) dalam mengajar, serta dapat meningkatkan proses pembelajaran siswa menjadi efektif dan interaktif. ${ }^{2}$ Dalam pembuatan suatu bahan ajar yang dapat digunakan dalam proses pembelajaran, harus dicermati dahulu komponen pembelajaran. Dengan demikian, pengembangan bahan ajar meupakan sistem terstruktur yang berisi komponen pembelajaran untuk menghasilakan suatu bahan ajar.

Sebagai sistem yang terstruktur, pengembanagan bahan ajar harus berpijak pada aturan yang telah ditentukan, sehingga dapat mengantarkan pada tujuan yang akan dicapai. Karena bertumpu pada tujuan pembelajaran, maka pengembangan bahan ajar ini memiliki banyak variasi. Penyebabnya adalah pengalaman guru dan kondisi lingkungan belajar yang berbeda-beda. Seorang pendidik harus kreativ dalam membuat bahan ajar yang menarik dan sesuai dengan kebutuhan peserta didik. ${ }^{3}$

Bahan ajar tersebut adalah bahan ajar screamble. Model pembelajaran ini dapat menimbulkan keterlibatan siswa dalam pembelajaran. Salah satu cara yang memungkinkan siswa terlibat aktif dalam pembelajaran adalah dengan menggunakan pembelajaran model screamble.Model ini diterapkan dalam pembelajaran akidah akhlak karena sudah disesuaikan dalam pemilihan materi.

\footnotetext{
${ }^{2}$ Andi Prastowo, Panduan Kreatif Membuat Bahan Ajar Inovatif, (Jogjakarta: DIVA Press, 2015), Cet 8, hlm. 24

${ }^{3}$ Andi Prastowo, Panduan Kreatif Membuat Bahan Ajar Inovatif, hlm.18
} 
Menurut Suharsimi Arikunto yang dikutip oleh B.Suryosubroto mengemukakan bahwa dasar pemilihan materi pelajaran sebagai berikut: Tujuan, Keadaan siswa, Situasi tempat, dan Tersedianya waktu dan fasilitas ${ }^{4}$

Adapaun alasan yang melatar belakangi peneliti dalam mengembangkan bahan ajar berbasis screamble yaitu bahan ajar cetak itu dapat digunakan berkelanjutan tidak hanya sebatas penelitian tetapi sampai pergantian tahun ajar dapat terus digunakan. Penggunaannya mudah dan praktis sehingga dapat digunakan oleh semua pihak.

Di dalam akidah akhlak biasanya terdapat istilah-istilah yang sulit untuk diingat oleh peserta didik. Maka model pembelajaran ini akan mengurangi beban bagi siswa dalam mengingat istilah yang sulit. Meningkatkan kemampuan dalam bekerja sama serta bersosialisasi dengan teman sekelas.

Bahan ajar screamble menjadi salah satu solusi yang bisa dipakai dalam proses pembelajaran. Beberapa alasan menggunakan bahan ajar berbasis screamble yaitu dapat meningkatkan konsentrasi siswa dan kecepatan dalam berfikir. Ini yang menjadi perbedaan dari bahan ajar biasa dengan bahan ajar berbasis screamble yang penulis kembangkan. Nantinya produk yang dikembangkan akan memberikan hasil tentang kelayakan bahan ajar dengan melihat respon siswa ketika proses pembelajaran.

Sekolah yang digunakan penulis untuk penelitian, ternyata masih berpegang pada bahan ajar konvensional dalam proses pembelajaran. Yaitu masih mengikuti kebiasaan yang umum dilakukan seorang pendidik dalam pembelajaran, artinya tidak ada variasi model yang digunakan dalam proses pembelajaran. Pendidik hanya berpegang pada buku paket yang disediakan oleh sekolah. Sehingga membuat peserta didik itu merasa bosan, mengantuk, dan malas mengikuti proses pembelajaran karena kurang menariknya media pembelajaran akidah akhlak. Hal tersebut dapat mempengaruhi hasil belajar peserta didik. Untuk mengatasi masalah tersebut pendidik perlu beralih penggunaan bahan ajar, tidak hanya bahan ajar konvensional

${ }^{4}$ B. Suryosubroto, Proses Belajar Mengajar di Sekolah, (Jakarta: Rineka Cipta, 2009), Cet 2, hlm. 27 
yang digunakan, melainkan bahan ajar baru yang di desain khusus untuk memudahkan peserta didik dalam memahami pelajaran kemudian dapat menarik siswa agar senang ketika belajar terutama dalam pelajaran akidah akhlak. Maka di sini penulis akan mengembangkan suatu produk baru yaitu bahan ajar berbasis screamble di MI NU Purwosari.

Berdasarkan permasalahan sebagaimana tersebut di depan, maka rumusan permasalahan penelitian ini adalah "Bagaimana pengembangan bahan ajar berbasis screamble pada mata pelajaran Akidah Akhlak Pokok Bahasan Akhlak Terpuji Nabi dan Rasul Kelas IV MI NU Purwosari Metro Utara?”

\section{Pembelajaran atau Pengajaran}

Pada dasarnya proses tindakan belajar bersifat internal yang dipengaruhi oleh faktor-faktor eksternal. Dalam proses pembelajaran pendidik dituntut mampu menarik perhatian siswa agar aktivitas belajar dapat berlangsung optimal dan memperoleh hasil belajar seperti yang diinginkan.

"Pembelajaran adalah suatu kombinasi yang tersusun meliputi unsu-unsur manusiawi, material, fasilitas, perlengkapan, dan prosedur yang saling mempengaruhi mencapai tujuan pembelajaran."5

Sedangkan menurut Degeng dalam buku Hamzah B Uno pembelajaran atau pengajaran yaitu upaya dalam membelajarkan siswa. Dalam pengertian ini secara implisit dalam pengajaran terdapat kegiatan memilih, menetapkan, mengembangkan metode untuk mencapai hasil pengajaran yang diinginkan. Pemilihan, penetapan, dan pengembangan metode ini didasarkan pada kondisi pengajaran yang ada. ${ }^{6}$

Dari pendapat para ahli di atas disimpulkan bahwasanya pembelajaran adalah kegiatan guru secara instruksional, untuk merencanakan pembelajaran agar mencapai tujuan pembelajaran. Sehingga memerlukan suatu perencanaan agar mencapai perbaikan dalam proses pembelajaran.

${ }^{5}$ Oemar Hamalik, Kurikulum dan Pembelajaran, (Jakarta: Bumi Aksara, 2008), Cet.8, hlm. 57

\footnotetext{
${ }^{6}$ Hamzah B. Uno, Perencanaan Pembelajaran, (Jakarta:Bumi Aksara, 2011), hlm. 2
} 
Karena sasaran akhir dari program pembelajaran yaitu tercapainya suatu tujuan umum pembelajaran tersebut. Oleh karena itu, setiap pendidik harus mempertimbangkan tujuan tersebut. Yang meliputi bidang studi, siswa dan kondisi lingkungan. ${ }^{7}$

Dalam melaksanakan tugasnya, kemampuan pendidik adalah sesuatu yang harus dimiliki.Keprofesionalan seorang pendidik dapat diukur dari pelakasanaan pembelajaran efektif serta efisien. Pembelajaran yang mendidik meliputi pemahaman suatu konsep dasar dari proses pendidikan serta pembelajaran pada bidang studi serta penerapanya dalam pelaksanaan dan pengembangan pembelajaran.

Dengan demikian pembelajaran memiliki arti yang sama dengan suatu perbuatan belajar dan mengajar. Kegiatan belajar mengajar yaitu suatu kesatuan anatara dua kegiatan yang searah. Kegiatan belajar merupakan kegiatan primer, sedangkan kegiatan mengajaryaitu kegiatan sekunder yang bertujuan agar kegiatan itu berlangsung secara optimal.

Seorang pendidik harus memiliki beragam metode dalam pembelajaran, karena mengingat banyaknya metodologi dalam suatu pembelajaran.Pendidik tidak hanya menggunakan satu metode dalam proses pembelajaran, tetapi menggunakan metode yang bervariasi, yang disesuaikan dengan kondisi, tipe belajar dan situasi siswa. Sehingga rumusan tujuan pembelajaran yang dibuat oleh pendidik dapat terwujud.

\section{Bahan Ajar}

Salah satu tugas bagi seorang pendidik yaitu mampu menyediakan suasana pembelajaran yang meyenangkan. Pendidik harus bisa mencari cara dalam membuat suatu pembelajaran yang menyenangkan. Cara yang bisa digunakan yaitu menggunakan bahan ajar yang dapat menarik perhatian siswa dan membuat senang untuk mempelajari bahan ajar tersebut.

\footnotetext{
${ }^{7}$ Dimyati \& Mudjiono, Belajar \& Pembelajaran, (Jakarta: PT Rineka Cipta, 2013), cet 5, hlm. 185
} 
Pada dasarnya bahan ajar merupakan suatu bahan yang berupa informasi, alat maupun teks yang tersusun secara sistematis, dimana di dalamnya berisi kompetensi yang wajib dikuasai oleh siswa serta digunakan dalam proses pembelajaran. ${ }^{8}$

Menurut Widodo dan Jasmadi yang dikutip oleh Ika Lestari, bahan ajar adalah seperangkat sarana atau alat pembelajaran yang berisikan materi pembelajaran, metode, batasan-batasan, dan cara mengevaluasi yang didesain secara menarik dalam rangka mencapai tujuan yang diharapkan, yaitu mencapai kompetensi atau subkompetensi dengan segala komplekstasnya. ${ }^{9}$

Dari beberapa pendapat diatas dapat peneliti sampaikan bahwa, bahan ajar merupakan suatu bahan yang sangat membantu seorang pendidik dalam melaksanakan proses kegiatan belajar mengajar. Bahan ajar atau biasa disebut dengan materi secara keseluruhan terdiri dari pengetahuan, sikap dan keterampilan yang dimiliki peserta didik dalam upaya mencapai suatu standar kompetensi yang telah ditentukan.

Menurut pendapat Arif dan Napitupulu dalam buku Andi Prastowo prinsip yang harus dilakukan dalam pemilihan bahan ajar adalah sesuai dengan tujuan pembelajaran, kebutuhan peserta didik, menggambarkan suasana yang dihayati peserta didik, mudah digunakan, sesuai dengan gaya dan lingkungan dimana bahan ajar itu digunakan ${ }^{10}$

Jenis pembelajaran secara terperinci terdiri dari pengetahuan (fakta, konsep, prinsi, prosedur), keterampilan dan sikap serta nilai yang mana harus dipelajari oleh peserta didik dalam upaya mencapai suatu standar kompetensi yang telah ditentukan.

Pemilihan suatu materi dalam pembelajaran memiliki prinsip yaitu, relevansi, konsisten dan kecukupan. Prinsip relevansi artinya materi pembelajaran harus berkaitan dengan pencapaian suatu standar kompetensi dan kompetensi dasar. Prinsip konsistensi yaitu bahan ajar dan kompetensi dasar yang harus dikuasai peserta didik harus ajeg. Mislanya, siswa harus menguasai empat macam kompetensi dasar, maka

${ }^{8}$ Andi Prastowo, Panduan Kreatif Membuat Bahan Ajar Inovatif, hlm. 17

9 Ika Lestari, Pengembangan Bahan Ajar Berbasis Kompetensi, (Padang:Akademia Permata, 2013), hlm. 1

${ }^{10}$ Andi Prastowo, Panduan Kreatif Membuat Bahan Ajar yang Inovatif, hlm.59 
ada empat macam pula bahan ajar yang diajarkan oleh pendidik. Prinsip kecukupan yaitu pengajaran kompetensi dasar yang harus dikuasai siswa harus meliputi materi yang cukup. Materi tidak boleh sedikit dan terlalu banyak. Jika sedikit, maka pencapaian standar kompetensi dan kompetensi dasar kurang berjalan dengan baik. Sebaliknya, jika banyak maka akan membuang waktu serta tenaga yang seharusnya tidak perlu dilakukan untuk mempelajarinya.

Pemilihan dan pengajaran materi yang dilakukan oleh guru kepada peserta didik hendaknya berisi materi serta bahan ajar yang bisa menunjang tercapainya suatu standar kompetensi dan kompetensi dasar.

\section{Model Pembelajaran Screamble}

Menurut Rober B.Taylor yang dikutip oleh Miftahul Huda menyatakan bahwa, Screambleyaitu salah satu metode yang digunakan dalam proses pembelajaran untuk meningkatkan konsentrasi serta kecepatan berpikir siswa. ${ }^{11}$

Metode pembelajaran ini mengharuskan setiap siswa untuk menggabungkan otak kanan serta otak kiri. Dalam metode ini, tugas siswa tidak hanya menjawab soal melainkan pula menerka jawaban pada soal yang masih diacak penyusunannya dengan waktu yang cepat.

Ketepatan dan kecepatan berpikir dalam menjawab soal menjadi salah satu kunci permainan metode pembelajaran Scramble. Skor yang diperoleh siswa ditentukan dengan banyaknya soal yang dijawab dengan benar dan cepat.

Sintaknya pembelajaran screamble menurut Ngalimun adalah membuat kartu soal sesuai dengan materi, membuat kartu jawaban dengan diacak nomornya, menyajikan materi, kemudian membagikan kartu soal serta jawaban pada kelompok, siswa bersama dengan kelompoknya masing-masing mengerjakan soal serta mencari jawaban yang cocok. ${ }^{12}$

A.

${ }^{11}$ Miftahul Huda, Model-Model Pengajaran dan Pembelajaran,(Yogyakarta: Pustaka Belajar),2013, Cet. 3, hlm. 303

${ }^{12}$ Ngalimun, Strategi dan Model Pembelajaran,(Yogyakarta: Aswaja Perkindo, 2013), Cet 2, hlm. 176 


\section{Pembahasan}

Terdapat 36 pernyataan dalam validasi ahli materi. Ahli materi melakukan validasi sebanyak dua kali. Berdasarkan data dapat diketahui hasil validasi ahli materi pada tahap I menunjukkan hasil dengan jumlah skor sebesar 112 sehingga rerata skor mencapai 3,1 dengan kategori layak. Pada validasi ahli materi pada tahap II menujukkan sangat layak. Berdasarkan penghitungan tersebut dapat dibuat konservasi skor validasi ahli materi yang diuraikain sebagai berikut.

Validasi yang dilakukan ahli materi dilakukan sebanyak dua kali. Validasi oleh ahli materi bertujuan agar produk bahan ajar berbasis screamble yang dikembangkan menjadi produk yang berkualitas secara aspek kesesuaian materi dan kelayakan penyajian.

Hasil Validasi Yang Dilakukan Ahli Materi Pada Tiap Aspek

\begin{tabular}{|c|c|c|c|}
\hline \multirow{2}{*}{ No } & \multirow{2}{*}{ Aspek yang dinilai } & \multicolumn{2}{|c|}{ Skor yang Diperoleh } \\
\cline { 3 - 4 } & & Tahap I & Tahap II \\
\hline 1 & Kesesuaian Materi & 51 & 55 \\
\hline 2 & Kelayakan Penyajian & 26 & 27 \\
\hline 3 & Penilaian Bahasa & 39 & 41 \\
\hline \multicolumn{2}{|c|}{ Jumlah } & 112 & 127 \\
\hline & Rerata Skor & 3,1 & 3,5 \\
\hline & Kategori Skor & Layak & Sangat Layak \\
\hline
\end{tabular}

Sumber: Data Primer Yang diolah

Rerata skor akhir validasi materi sebesar 3,5 berada dalam kategori sangat

layak. Berdasarkan hasil di atas dapat diketahui bahwa bahan ajar berbasis screamble pada pelajaran Akidah Akhlak yang dikembangkan layak untuk digunakan secara aspek pembelajaran dan kebahasaan. Peniliaian produk oleh ahli materi berdasarkan 
rerata skor, disajikan dalam diagram berikut ini:

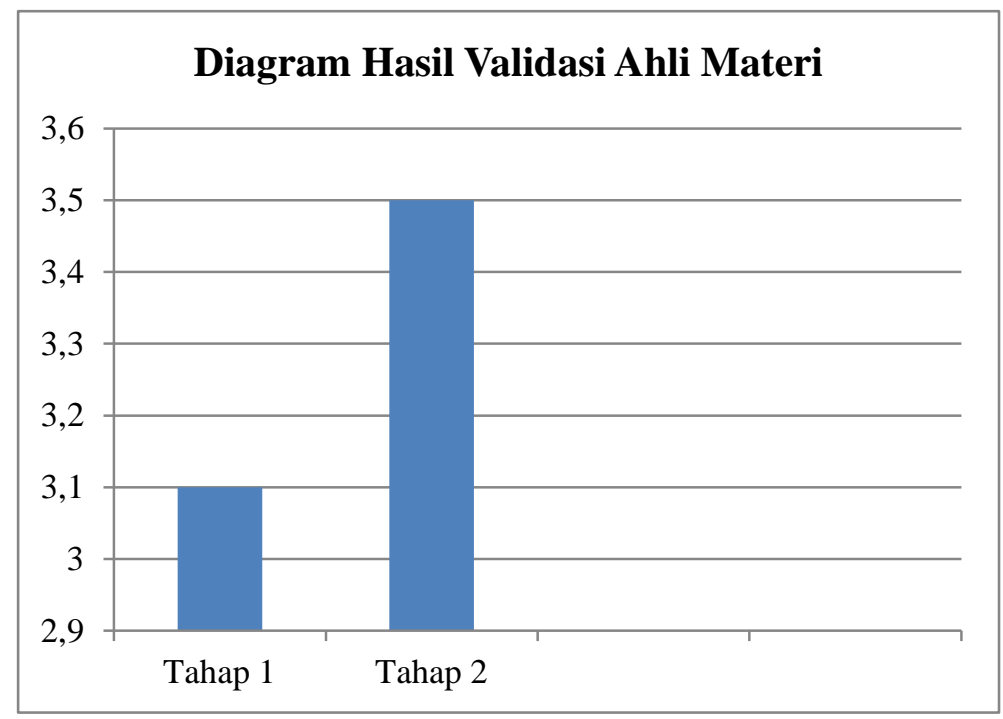

Diagram hasil Oleh validasi ahli materi

Pada hasil validasi ahli materi terdapat 38 pernyataan dalam lembar validasi ahli media. Berdasarkan data dapat diketahui hasil validasi ahli media yang dilakukan pada tahap I menunjukkan hasil skor sebesar 106 dan rerarta skor 2,7 dengan kategori "layak". Pada validasi ahli media yang dilakukan tahap II menunjukkan hasil jumlah dengan skor sebesar 132 rerata sebesar 3,47 dengan kategori "sangat layak".

Validasi pada ahli media dilakukan sebanyak dua kali. Validasi ini bertujuan agar produk yang dikembangkan berupa bahan ajar berbasis screamble menjadi produk yang berkualitas secara aspek penerapan dan tampilan. Hasil perhitungan validasi tersebut pada tiap aspek dapat diatur dalam tabel di bawah ini.

\section{Hasil Validasi Media Pada Tiap Aspek}

\begin{tabular}{|c|c|c|c|}
\hline \multirow{2}{*}{ No } & \multirow{2}{*}{ Aspek yang dinilai } & \multicolumn{2}{|c|}{ Skor yang Diperoleh } \\
\cline { 3 - 4 } & Tahap I & Tahap II \\
\hline 1 & Ukuran Bahan Ajar & 5 & 7 \\
\hline 2 & Desain Sampul & 17 & 23 \\
\hline 3 & Desain Isi Bahan Ajar & 44 & 58 \\
\hline 4 & $\begin{array}{c}\text { Kesesuaian materi dengan model } \\
\text { pembelajaran screamble }\end{array}$ & 8 & 8 \\
\hline
\end{tabular}




\begin{tabular}{|c|c|c|c|}
\hline 5 & $\begin{array}{c}\text { Karakteristik model pembelajaran } \\
\text { screamble }\end{array}$ & 13 & 16 \\
\hline 6 & Prinsip model screamble & 19 & 20 \\
\hline Jumlah & $\mathbf{1 0 6}$ & $\mathbf{1 3 2}$ \\
\hline Rerata Skor & $\mathbf{2 , 7}$ & $\mathbf{3 , 4 7}$ \\
\hline Kategori Skor & Layak & $\begin{array}{c}\text { Sangat } \\
\text { Layak }\end{array}$ \\
\hline
\end{tabular}

Sumber: Data Primer Yang diolah

Berdasarkan hasil tersebut, dapat diketahui bahwa produk yang dikembangkan yaitu bahan ajar berbasis screamble layak untuk digunakan secara aspek desain dan tampilan. Peniliaian produk oleh ahli materi berdasarkan rerata skor, disajikan dalam diagram berikut ini:

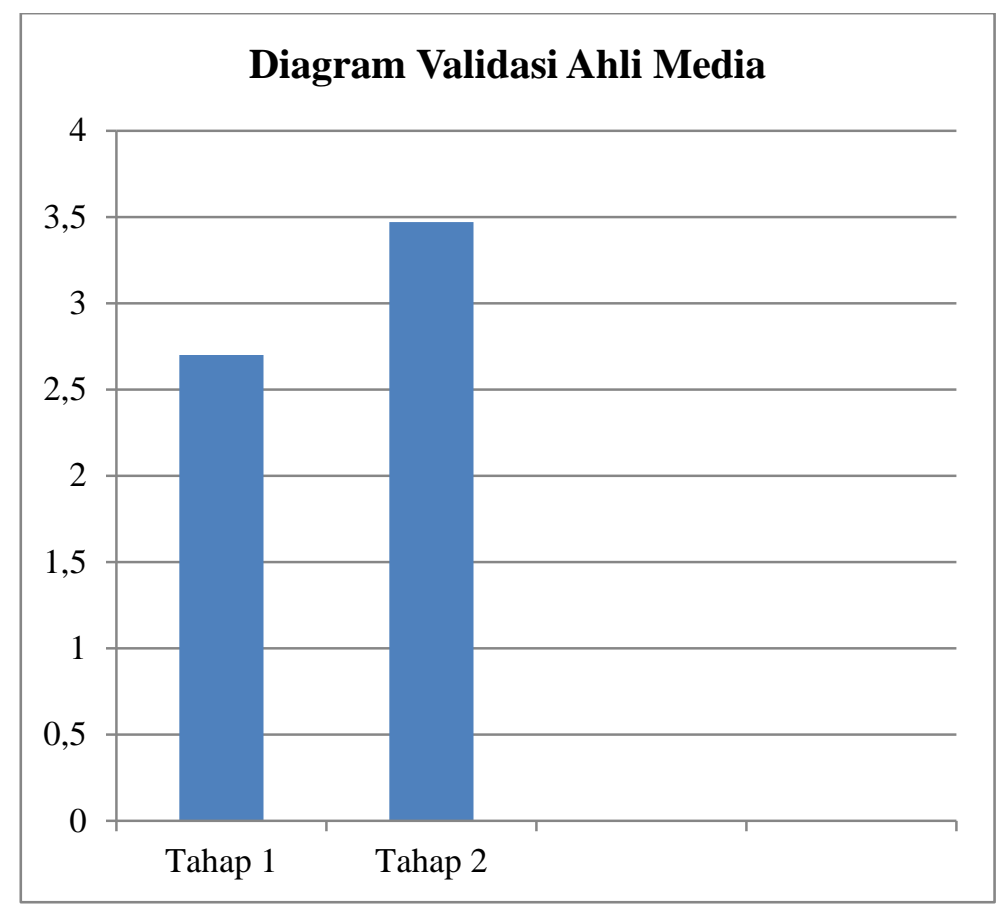

Diagram Validasi Ahli Media

Penelitian dan pengembangan yang dilakukan menggunakan uji penggunaan untuk mengetahui respon guru dan siswa terhadap bahan ajar berbasis screamble pada pelajaran Akidah Akhlak yang dikembangkan. Uji penggunaan bahan ajar oleh guru dan siswa dilakukan dalam uji coba kelompok kecil (terbatas) dan uji coba kelompok 
besar (uji pemakaian). Data yang diperoleh kemudian diolah untuk melihat hasil akhir dari uji penggunaan bahan ajar, dari rata-rata skor yang diperoleh dan kategorinya. Perhintungan rata-rata dari data yang diperoleh bertujuan untuk mengetahui kelayakan bahan ajar berbasis screamble pada mata pelajaran Akidah Akhlak dengan materi akhlak terpuji nabi dan rasul kelas IV.

Dalam uji coba terbatas dilakukan sama halnya dengan pembelajaran Akidah Akhlak di kelas. Hal tersebut dilakukan agar guru dan siswa benar-benar merasakan bagaimana pengalaman mereka apabila menggunakan bahan ajar berbasis screamble. Uji penggunaan produk dilakukan secara terbatas terlebih dahulu untuk meminimalisir apabila terjadi kesalahan fatal, misalnya penulisan konsep materi yang tidak tepat ataupun bahan ajar yang tidak memenuhi sasaran, sehingga untuk mengklarifikasinya lebih mudah dalam jumlah yang terbatas. Selain itu, dilakukannya uji coba terbatas juga untuk mengetahui peningkatan kualitas bahan ajar berbasis screamble pada mata pelajaran Akidah Akhlak dengan materi akhlak terpuji nabi dan rasul, karena berdasarkan uji penggunaan bahan ajar berbasis screamble oleh satu guru dan 6 orang siswa, dapat membantu menemukan kesalahan-kesalahan yang perlu diperbaiki, serta melihat respon dari guru dan siswa.

Selanjutnya dilakukan revisi produk berdasarkan hasil uji coba kelompok kecil (terbatas) untuk penyempurnaan sesuai dengan komentar dan saran dari guru dan siswa. Revisi produk dilakukan untuk mengurangi kesalahan dan menghasilkan bahan ajar berbasis screamble yang lebih baik lagi dan dipersiapkan untuk uji coba satu kelas.

Setelah uji coba terbatas, dilakukan uji pemakaian. Subjek dalam uji coba kelompok besar (uji pemakaian) dilakukan guna mendapatkan informasi mengenai tanggapan guru dengan siswa terhadap produk yang dikembangkan yaitu bahan ajar berbasis screamble. Dalam uji coba kelompok besar, dilakukan sama halnya dengan pembelajaran Akidah Akhlak di kelas. Uji penggunaan media terbatas serta dalam uji pemakaian melibatkanguru dan siswa karena mereka adalah pelaku dalam kegiatan pembelajaran Akidah Akhlak. Oleh sebab itu, saran, masukan, dan komentar dari 
guru dan siswa dapat membantu penyempurnaan bahan ajar berbasis screamble. Berikut adalah pembahasan hasil uji coba oleh guru dan siswa.

\section{Hasil Uji Coba Penggunaan Bahan Ajar Berbasis Screamble oleh Guru}

Terdapat 30 pernyataan dalam angket guru. Dari rata-rata tersebut diketahui skor tertinggi adalah 4 , dan skor terendah adalah 1 . Uji penggunaan produk oleh guru dilakukan seorang guru Akidah Akhlak. Berdasarkan hasil tabel uji penggunaan media oleh guru, dapat peneliti simpulkan bahwa bahan ajar berbasis screamble yang dikembangkan oleh peneliti melewati 2 kali uji penggunaan.Selama dua kali uji penggunaan tersebut, peneliti sebagai pengembang mendapatkan hasil penelitian yang meningkat. Rata-rata skor dari uji penggunaan mengalami kenaikan dan perbaikan. Uji penggunaan bahan ajar berbasis screamble dalm uji coba terbatas memperoleh rata-rata skor sebesar 2,93 atau dengan kategori layak. Pada uji coba pemakaian (kelompok besar) diperoleh rata-rata skor sebesar 3,6 dengan kategori sangat layak. Hal tersebut menunjukkan adanya perbaikan dari bahan ajar berbasis screamble. Dari rata-rata skor uji penggunaan tersebut dapat dijelaskkan grafik sebagai berikut.

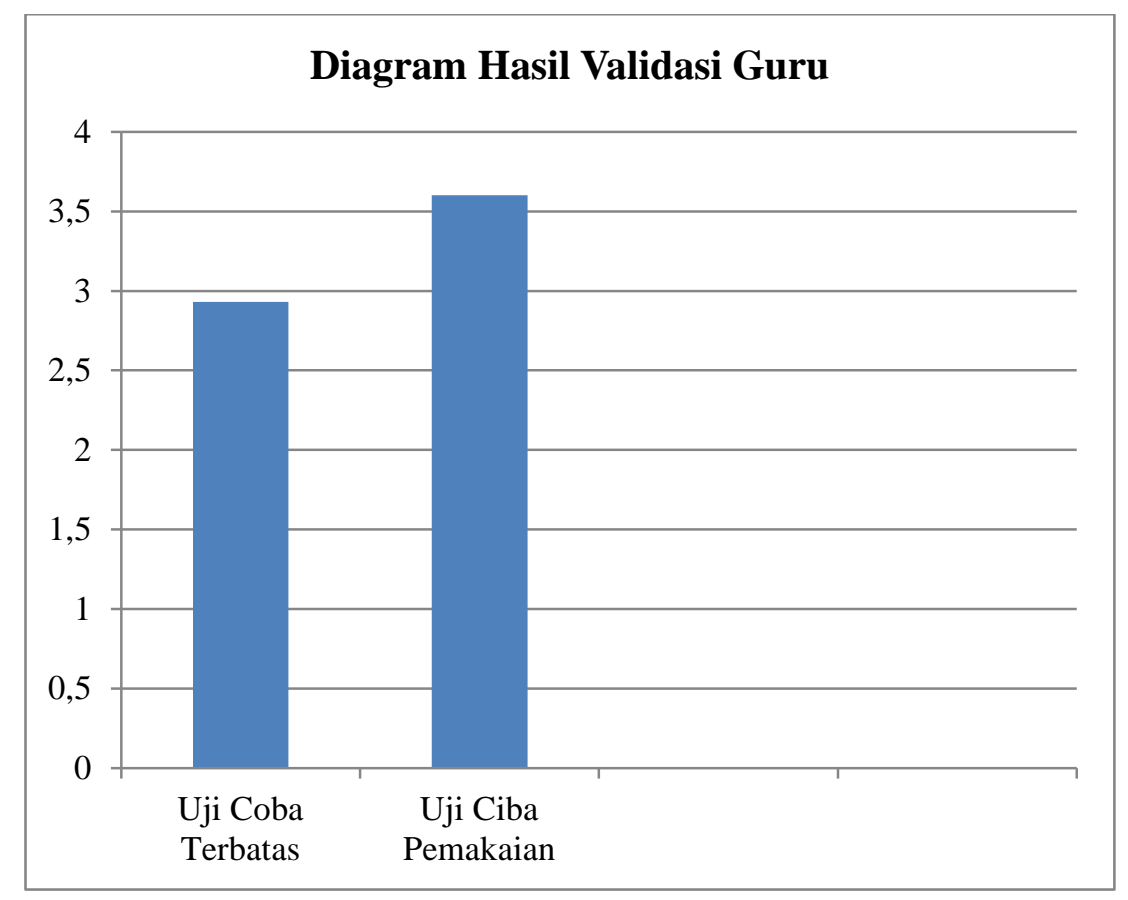

Hasil Validasi Guru 
Rata-rata skor akhir yang diperoleh adalah 3,6 berada pada kategori sangat layak. Dapat peneliti simpulkan bahwa bahan ajar berbasis screamble pada mata pelajaran Akidah Akhlak pokok bahasan akhlak terpuji nabi dan rasul kelas IV yang telah dikembangkan oleh peneliti layak digunakan.

\section{Hasil uji Penggunaan Bahan Ajar Berbasis Screamble oleh Siswa}

Terdapat 13 pernyataan dalam angket untuk siswa. Uji penggunaan bahan ajar bebasis screamble oleh siswa dilakukan dalam kelas IV yang dikembangkan oleh peniliti melewati 2 kali uji penggunaan oleh siswa, yaitu uji coba dalam kapasias terbatas dan uji coba pemakaian (kelompok besar). Subjek uji penggunaan bahan ajar oleh siswa dalam uji coba yang dilakukan secara terbatas sebanyak 6 siswa, sedangkan subjek uji coba pemakaian sebanyak 27 siswa.

Berdasarkan tabel hasil uji penggunaan bahan ajar berbasis screamble oleh siswa, dapat disimpukan bahwa kualitas bahan ajar berbasis screamble yang dikembangkan oleh peneliti mengalami peningkatan berdasarkan uji coba pemakaian atau uji kelompok. Uji penggunaan bahan ajar berbasis screamble dalam uji coba yang dilakukan secara terbatas memperoleh rata-rata skor sebesar 3,63 atau dengan kategori sangat layak.

Dalam uji pemakaian atau uji kelompok besar memperoleh rata-rata skor sebesar 3,76. Peningkatan kualitas bahan ajar berbasis screamble, didukung oleh revisi yang dilakukan setelah uji coba terbatas.Pada saat uji coba terbatas, terdapat langkah-lengkah pembelajaran yang belum diketahui oleh siswa.Berdasarkan revisi tersebut, bahan ajar berbasis screamble diperbaiki sesuai dengan saran serta komentar dari setiap siswa sehingga saat dilakukan uji coba pemakaian terdapat peningkatan kualitas bahan ajar berbasis screamble.

Dari rata-rata skor uji penggunaan tersebut dapat dijelaskan melalui grafik sebagai berikut 


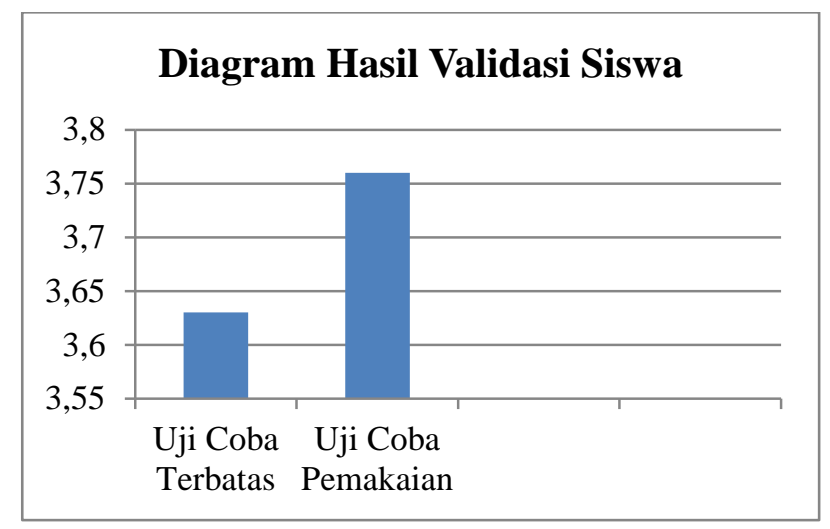

\section{Hasil Validasi Siswa}

Dari grafik di atas, dapat peneliti simpulkan bahwa bahan ajar berbasis screamble yang telah dikembangkan oleh penliti sangat layak digunakan.

Berdasarkan uraian di atas, dapat diketahui bahwa rata-rata skor hasil validasi pada ahli materi sebesar 3,5 dengan kategori sangat layak, hasil vaidasi ahli media sebesar 3,4, hasil akhir uji penggunaan bahan ajar oleh guru sebesar 3,6 dengan kategori sangat layak, dan hasil akhir ui penggunaan bahan ajar oleh siswa sebesar 3,76 dengan kategori sangat layak.

Hasil tersebut dapat digambarkan dalam grafik sebagai berikut:

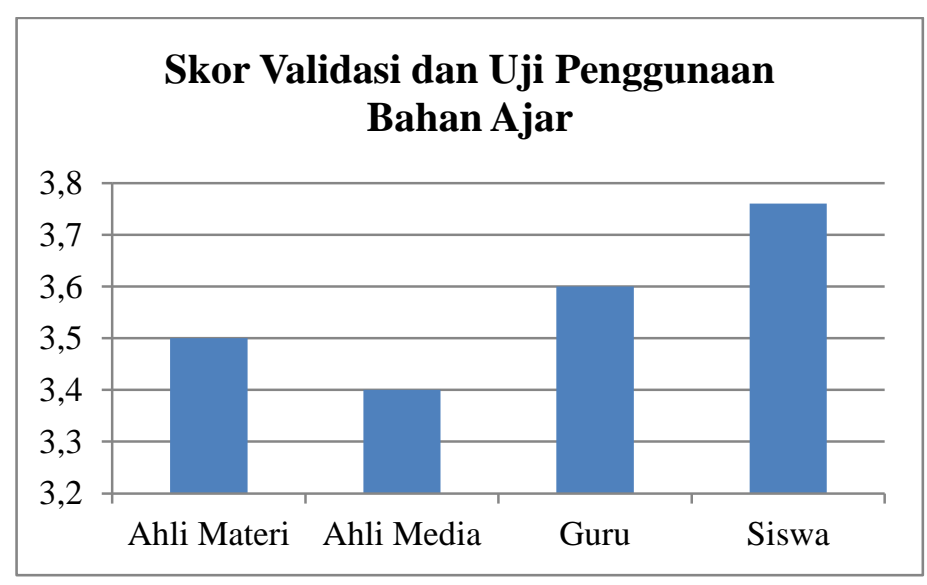

\section{Skor Validasi dan Uji Pemakaian Bahan Ajar}

Secara keseluruhan, hasil tersebut menunjukkan bahwa bahan ajar berbasis screamble yang dikembangkan pada penelitian pengembangan ini dinyatakan layak untuk digunakan dengan kualitas yang baik.Bahan ajar berbasis screamble juga siap diproduksikan dalam jumlah yang lebih banyak untuk diterapakan di sekolah lainnya. 
Produk yang dihasilkan dari penelitian dan pengembangan bahan ajar ini berupa bahan ajar yang berbasis screamble yaitu sebuah buku ajar Akidah Akhlak untuk kelas IV di MI NU Purwosari. Bahan ajar berbasis screamble tidak hanya mengajarkan pengetahuan tentang akidah dan akhlak, akan tetapi mengajarkan membentuk kepribadian siswa agar memiliki keimanan dan ketaqwaan dalam kehidupannya yang senantiasa selalu dihiasi dengan akhlak yang baik dimanapun mereka berada dan dalam posisi apapun serta mendorong mereka untuk mengamalkannya, sekaligus membentuk akhlak sesuai dengan yang dimiliki nabi dan rasul untuk menerapkannya dalam kehidupan sehari-hari.

Produk hasil pengembangan berupa bahan ajar berbasis screamblepada mata pelajaran Akidah Akhlak dengan materi akhlak terpuji nabi dan rasul yang berbentuk bahan ajar ini memiliki sejumlah kelebihan baik secara internal maupun ekternal antara lain:

Kelebihan, Secara internal bahan ajarscreamble ini memiliki beberapa kelebihan yaitu: (1) bahan ajar dapat digunakan sebagai bahan ajar alternatif di sekolah, (2) bahan ajar ini memberikan pengetahuan baru baik bagi guru ataupun siswa, (3) produk hasil pengembangan yang dilakukan dapat dijadikan pedoman untuk pembelajaran berikutnya, (4) produk hasil pengembangan bahan ajar ini dapat digunakan sebagai penuntun pembelajaran secara mandiri.

Kekurangan, Adapun kelemahan produk pengembangan berupa bahan ajar ini antara lain : (1) hanya dapat digunakan pada sekolah yang mayoritas muslim, karena materinya tentang agama, (2) masih kurang dalam desain pembelajarannya dan desain modulnya, (3) peneliti masih merasa produk ini harus dikembangkan lagi untuk mendapatkan presentase yang maksimal, (4) peneliti masih merasa produk ini mempunyai kekurangan dalam referensi materi maupun pembuatan soal-soal latihan. 


\section{Kesimpulan}

Penelitian dan pengembangan ini menghasilkan produk berupa bahan ajar berbasis screamble pada mata pelajaran Akidah Akhlak pokok bahasan akhlak terpuji nabi dan rasul kelas IV. Tahapan yang dilakukan menghasilkan bahan ajar berbasis screamble sebagai berikut: a) tahap pengumpulan informasi, b) tahap perencanaan, c) tahap pengembangan, dan d) tahap validasi dan uji coba. Materi di dalam bahan ajar ini berupa akhlak terpuji nabi dan rasul yaitu sidiq, amanah, tabligh, dan fathanah. Pada proses pembelajaran siswa dibagi menjadi 4 kelompok untuk mengerjakan soal yang telah dibuat secara berkelompok. Dengan aturan permainan yang telah ditentukan. Pada setiap tahapan, siswa diminta untuk cepat dalam mengerjakan soal karena dibatasi oleh waktu, serta siswa dituntut untuk saling bekerja sama dalam kelompok masing-masing.

Berdasarkan validasi oleh ahli materi dan media, dapat diketahui hasil validasi terhadap ahli materi sebesar 3,5 dengan kategori sangat layak, dan hasil validasi ahli media sebesar dengan kategori sangat layak. Serta dalam uji coba pemakaian oleh guru diperoleh hasil sebesar 3.6 dengan kategori sangat layak dan uji coba pemakaian oleh siswa memperoleh hasil sebesar 3.76 dengan kategori sangat layak. Dari keseluruhan validasi menunjukkan hasil yang sangat baik, sehingga produk bahan ajar berbasis screamble layak digunakan.

\section{Saran}

Bahan ajar berbasis screamble diharapkan dapat diterapkan di sekolahsekolah karena akan memudahkan siswa dalam memahami materi yang disajikan. Mengingat hasil produk penelitian dan pengembangan dapat memberikan manfaat terhadap proses pembelajaran, maka disarankan kepada seluruh pendidik untuk mengembangkan produk ini dengan cakupan wilayah yang lebih luas. Perlunya dilakukan pengembangan lebih lanjut terhadap bahan ajar screamble untuk meningkatkan kualitas dalam pembelajaran terutama Akidah Akhlak di MI. 


\section{DAFTAR PUSTAKA}

Anwar, Rosihin, Akidah Akhlak, (Bandung: CV Pustaka, 2008), Cet.1.

B. Suryosubroto, Proses Belajar Mengajar di Sekolah, (Jakarta: Rineka Cipta, 2009),

Cet 2.

B. Uno, Hamzah, Perencanaan Pembelajaran, (Jakarta: Bumi Aksara, 2008).

Departemen Agama Republik Indonesia, Al-Qur'an dan Terjemah, (Bandung: Diponegoro, 2010).

Departemen Pendidikan Nasional Direktorat Jenderal Manajemen Pendidikan Dasar dan Menengah Direktorat Pembinaan Sekolah Menengah Atas, Panduan Pengembangan Bahan Ajar, Tahun 2008

Dimyati \& Mudjiono, Belajar \& Pembelajaran, (Jakarta: PT Rineka Cipta, 2013), cet 5.

Fitri Erning Kurniawati, "Pengembangan Bahan Ajar Aqidah Akhlak Di Madrasah Ibtidaiyah", dalam: Jurnal Penelitian, Vol 9, No 2, Agustus 2015.

Hamalik, Oemar, Kurikulum dan Pembelajaran, (Jakarta: Bumi Aksara, 2008), Cet.8. Heni Setyawati, "Pengembangan Perangkat Pembelajaran Berbasis Masalah Untuk Meningkatkan Keterampilan Proses Sains Siswa”, dalam: Jurnal Bioedukasi, Vol. XV, No.1, April 2017.

Huda, Miftahul, Model-Model Pengajaran dan Pembelajaran, (Yogyakarta: Pustaka Belajar), 2015, Cet. 6.

Kementrian Agama Republik Indonesia, Buku Siswa Akidah Akhlak Madrasah Ibtidaiyah Kelas IV, (Jakarta: Kementrian Agama Republik Indonesia, 2014), Cet. 1 .

Lestari, Ika, Pengembangan Bahan Ajar Berbasis Kompetensi, (Padang: Akademia Permata, 2013).

Masnati, "Penerapan Model Pembelajaran Screamble Untuk Meningkatkan Kemampuan Membaca Puisi Siswa Kelas V SD Negeri 020 Tembilahan Hilir", dalam: Jurnal Pajar (Pendidikan dan Pengajaran) Program Studi Pendidikan Guru Sekolah Dasar FKIP Universitas Bandung, Vol 1, No 2, November 2017. 
Narbuko, Cholid \& Abu Achmadi, Metodologi Penelitian, (Jakarta: PT Bumi Aksara, 2013), Cet 13.

Nazir, Moh, Metode Penelitian, ( Bogor Selatan: Ghalia Indonesia, 2005).

Ngalimun, Strategi dan Model Pembelajaran, (Yogyakarta: Aswaja Perkindo, 2013), Cet 2.

Ni Luh Deviana, dkk, Model Pembelajaran Ajaran Kooperatif Tipe Screamble Berbantuan Bahan Manipulatif Berpengaruh Terhadap Kompetensi Pengetahuan Matematika, Vol. 1, No. 2, 2 Agustus 2015.

Nusa Putra, Research \& Development, ( Jakarta: PT Raja Grafindo Persada, 2015), Cet4.

Prastowo, Andi, Panduan Kreatif Membuat Bahan Ajar Inovatif, (Jogjakarta: DIVA Press, 2015), Cet 8.

Sanjaya, Wina, Perencanaan \& Desain Sistem Pembelajaran, (Jakarta: Kencana Group, 2013), Cet 6.

Sadewi, N.M Putri, N Nym. Kusmariyatni, Penerapan Model Pembelajaran Screamble Untuk Meningkatkan Hasil Belajar IPA Siswa, Vol 1, No 3, November 2017

Saebani, Beni Ahmad dan Abdul Hamid, Ilmu Akhlak, (Bandung: CV Pustka Setia, 2010).

Seri Peningkatan Kompetensi dan Kinerja Guru, Kegiatan Pembelajaran yang Mendidik, ( Jakarta: Rineka Cipta, 2014).

S. Margono, Metodologi Penelitian Pendidikan, (Jakarta: PT Rineka Cipta, 2014), Cet 9.

Sukardi, Metode Penelitian pendidikan Tindakan Kelas, (Jakarta: PT Bumi Aksara, 2013).

Sugiyono, Metode Penelitian Kuantitatif Kualitatif dan R\&D,(Bandung: Alfabeta, 2012), Cet 17.

Sukmadinata, Nana Syodih, Metode Penelitian Pendidikan, (Bandung:PT Remaja Rosdakarya, 2016), Cet 12. 
Suprijono, Agus, Cooperative Learning, (Yoyakarta: Pustaka Belajar, 2014), Cet 13.

Suyatinah, Pengembangan Model Pembelajaran Membaca Permulaan Dengan Teknik Screamble Siswa Kelas Rendah, Vol 5, No 2, September 2012.

Undang-Undang Sisdiknas (Sistem Pendidikan Nasional), (Jakarta: Sinar Grafika, 2009), Cet II. 